\title{
The implementation of the Marketing Communication Mix using Internet Platforms on Turkish Cypriot Hotels
}

\author{
Zead M. Alhawamdeh ${ }^{1}$ \\ ${ }^{1}$ Faculty of Economics and Administrative Sciences, Jerash University, Jordan \\ Correspondence: Zead M. Alhawamdeh, Faculty of Economics and Administrative Sciences, Jerash University, \\ Jordan. E-mail: alhawamdeh@hotmail.co.uk \\ Received: January 6, 2019 \\ doi:10.5539/ijbm.v14n3p124
}

\begin{abstract}
The advent of the internet has reshaped the way humans live, and the way business is done globally. Although the tide of globalization had set in long before the advent of the internet, the coming of the internet expedited it. This is even more so for the field of tourism which relies on the cross cultural and global fascination the world's citizens hold for the various 'other sides' of the planet. The benefits of marketing through the internet is for some an overwhelming phenomena. Tourism forms have however had to catch up fast. Today the internet is used in such marketing schemes as online sales promotion, online advertising, Thus the traditional marketing communications mix have been found to have a new avenue in the world wide web. This study set out to understand the rate at which North Cyprus hoteliers are catching up and more specifically to understand how elements of the marketing communications mix are deployed through their websites. Three, four and five star hotels graded by the North Cyprus Hoteliers Association known as KITOB were used as the sample population for this study.
\end{abstract}

Keywords: internet marketing, marketing communication, advertising, sales promotion, web site, hotels

\section{Introduction}

According to George (2001) and Zeithaml and Bitner (2003) the marketing mix is one of the most fundamental concepts in marketing. Traditionally, it has always been comprised of four principal components: price, product, place [distribution] and promotion-which according to Armstrong and Kotler, (2005); and Belch \& Belch, (2004) are collectively called the "Four Ps" of marketing. Among the many functions of marketing, perhaps one of its most important and most basic functions is the effective combination of the four components of the marketing mix in the creation of successful marketing programmes which provide avenues for interaction between firms and their consumers in the general market place (Belch \& Belch, 2004). In the light of the above and from the general concept of the marketing mix, this proposed dissertation research is concerned with only the Promotion component of the "Four Ps" of marketing.

According to Armstrong and Kotler (2005) the promotional component of the "Four Ps" of marketing or the marketing mix is the component responsible for communicating the value of the organization's product or services to its target market and convinces them to buy or acquire it. Semenik (2002) adds that the promotional component plays a pivotal role in the marketing mix because the successful execution of the three other components depends on it.

According to Shimp (2003) marketing communications is a critically important element of contemporary marketing; a pivotal component of the total marketing strategy of firms and a crucial determining force behind firm success. Some schools of thought even hold that in reality, communications and marketing are not separate, but are one and the same (Shimp, 2003).

In essence, marketing communications is contemporarily a collective terminology used to refer to all the communications functions applied towards successfully marketing a service or product (Duncan, 2002). Although it can be argued that some form of communication occurs through the other components of the marketing mix, the majority of an organization's market targeted communications however is as a result of the development and execution of carefully thought out marketing communications programmes. Belch and Belch, (2004) reveals that to successfully develop and execute such marketing communications programmes, firms 
utilize a group of elements known as the marketing communications mix.

A review of literature reveals that there is a fundamental difference in opinion regarding the components of the marketing communications mix as can be seen in the works of Semenik (2002); Shimp (2003); Du Plessis Bothma, Jordaan and van Heerden (2003); and Lamb, Hair, McDaniel, Boshoff and Terblanché (2004). However, Belch \& Belch, (2004) revealed that the marketing communications mix was traditionally composed of four basic components: sales promotion, advertising, personal selling and public relations.

\subsection{Problem Statement}

Even though marketing communications is a common purpose of all Web sites (Du Plessis etal., 2003), no previous research has examined ways in which the marketing communications mix elements could be applied via a tourism firm's Web site.

\subsection{Objectives of the Study}

Considering the problem statement presented in section 4 , the following specific objectives were formulated for this study: To identify, through a review of available literature, a number of online marketing communications techniques for the various elements of the marketing communications mix (i.e., advertising, sales promotion, public relations and personal selling) that could be applied via a tourism firm's Web site.

\subsection{Research Questions}

\subsubsection{General Research Question}

In order to achieve these objectives, the general research question: To what extent do graded hotels in North Cyprus apply elements of the internet marketing communications mix through their websites?

\subsubsection{Advertising}

- Research question 1: To what extent do the Web sites to be investigated in this study provide links to other sites?

\subsubsection{Sales Promotion}

- Research question 2: To what extent do the Web sites to be investigated in this study offer something free?

1.3.4 Public Relations

- Research question 3: To what extent to be Web sites investigated in this study provide frequently asked questions (FAQ) section?

\subsubsection{Personal Selling}

- Research question 4: To what extent do the Web sites to be investigated in this study provide an online booking facility?

\subsection{Limitations}

This study is not without its limitations. The study was restricted to three, four and five star hotels alone, and to only hotels graded by KITOB the North Cyprus Hoteliers Association.

\section{Methodology}

The research design applied in this study is based on the classification scheme provided by Cooper and Schindler (2003). Taking this scheme into account, this will be a formal study and purely descriptive in nature. A monitoring (i.e., observation) process will be applied as data will be collected following a content analysis approach and there will be no attempt to elicit responses from anyone. As this study aims to merely report what was found during the data collection period and also, there will be no attempt to control or manipulate any of the variables, since an ex post facto research design will be followed.

This study will also be a statistical study as numeric inferences will be made based on a census of Websites that are independently owned by graded hotels. It will also be cross-sectional as research will only be carried out on one occasion under field conditions as it will be conducted under actual environmental conditions.

The measuring instrument in this study will be a code sheet which will be compiled based on an extensive literature review. This study will investigate the presence or absence of specific online marketing communications techniques in the Web sites of graded hotels based on this code sheet.

\section{Previous Study}

The global tourism industry in some geographic and scholarly spheres has been often described and referred to 
as an elaborate system or complex activity (Lubbe, 2003). When it is referred to in the widely held context of an industry, it is as a consequence of the measurability of its economic impact. According to the World Travel and Tourism Council (WTTC) the tourism industry is a "network of businesses that are engaged in the transport, accommodation, feeding, entertainment and care of the traveler" (Lubbe, 2003). The measurability of this unique industry is directly linked to the factors and interplay of demand and supply. In this regard, the WTTC categorizes the following factors as the key determinants of demand in the industry: "consumer, business and government travel expenditure". Lube (2003) however, notes that the supply aspect of this interplay is a mere reflection of the total inputs necessary to produce goods and services which meet the needs of the traveler.

Also in their work, Bennett et al. (2005) corroborated both previously mentioned scholars when they posited that "tourism is deemed to include any activity concerned with the temporary short-term movement of people to destinations outside the places they normally live and work, and their activities during their stay at these destinations".

Finally, the viewpoint that tourism is an activity is further reflected in the accepted and standard definition of tourism as defined by the World Tourism Organization (WTO). In 2002, the organization defined tourism as "the activities of persons travelling to and staying in places outside their usual environment for not more than one consecutive year for leisure, business and other purposes not related to the exercise of an activity remunerated from within the place visited". These definitions and postulations all serve to reject the notion that Tourism is an industry and uphold the perception of Tourism as a complex chain of activities. However, as mentioned at the onset, Tourism is also perceived to be a system.

For the school of thought which perceives tourism as a system they all seem to be of a consensus that tourism is a system of demand and supply. This perception intricately implies that tourism is both an industry and an activity. The activity aspect of tourism is viewed in this school of thought as the demand side while the industry aspect of tourism is viewed as the supply side.

According to (Lubbe, 2003) this school of thought is of the opinion that the supply and demand aspects of tourism are connected and made possible via marketing channels, research and development, distribution networks, global and national tourism organizations and transportation outlets. Lubbe also noted that environment plays a pivotal role in determining the nature of demand and supply interaction in tourism and this is attributed to unique ability of an environment to convey the historical, existential, futuristic, technological and socio-economic situation of an environment (Lubbe, 2003).

Therefore, tourism can be viewed as a system where all these components relate to one another and are interdependent. Within this system, the components of tourism are not strictly separated into supply and demand sides. Instead they are viewed as a set of interrelated parts in which the entire system is affected by changes (Lubbe, 2003).

\section{Result}

The websites of three, four and five star hotels were analyzed to understand how Hotels in North Cyprus applied elements of the marketing communications mix on their websites. All in all a total of 33 websites were analyzed for all three grade levels. These websites were analyzed using Ngai's (2003) model and Table 2 below, presents a general summary of the findings for each element of the marketing communications mix as observed. 
Table 1. Summary of the application of marketing communications mix for $3,4 \& 5$ star hotels in North Cyprus

\begin{tabular}{|c|c|c|}
\hline Categories and online marketing communications techniques & $\begin{array}{l}\text { Frequency with which } \\
\text { technique was employed } \\
(n=33)\end{array}$ & $\begin{array}{l}\text { Percentage with which } \\
\text { techniques was employed } \\
(\mathrm{n}=33)\end{array}$ \\
\hline \multicolumn{3}{|l|}{ Advertising } \\
\hline Links to other sites & 33 & 100 \\
\hline \multicolumn{3}{|l|}{ Sales Promotion } \\
\hline Coupons, discount and/or Special offers & 10 & 30.30 \\
\hline Offer Something Free & 5 & 15.15 \\
\hline Connection to loyalty programme & 2 & 6.25 \\
\hline Win something & 0 & 0.00 \\
\hline Online Games & 0 & 0.00 \\
\hline \multicolumn{3}{|l|}{ Public Relations } \\
\hline Photo Gallery & 33 & 100.00 \\
\hline Online Guest book & 27 & 81.81 \\
\hline Registration to receive a newsletter & 15 & 45.45 \\
\hline Press releases & 10 & 30.30 \\
\hline Recommend site to a friend & 7 & 21.21 \\
\hline Press Centre & 14 & 42.42 \\
\hline Send e-post cards & 0 & 0.00 \\
\hline \multicolumn{3}{|l|}{ Personal Selling } \\
\hline Online Booking facility & 33 & 100.00 \\
\hline
\end{tabular}

A summary of the average percentage of occurrence of each element of the marketing communications mix irrespective of hotel grade level category is presented in Table 2. Note that descriptive analysis of all websites observed revealed that all of the hotels observed irrespective of grade category applied one or more techniques of the advertising and personal selling elements of the marketing communications mix.

Table 2. Average percentages calculated for the 4 marketing communications mix categories $(\mathrm{n}=33)$

\begin{tabular}{ll}
\hline Marketing communications mix category & Average Percentage \\
\hline Advertising & 100.00 \\
Public relations & 45.88 \\
Sales Promotion & 3.40 \\
Personal selling & 100.00 \\
\hline
\end{tabular}

Also $61.5 \%$ of all of the websites observed applied some direct marketing techniques, while $45.88 \%$ of the websites observed applied one or more techniques of public relations. However, very few websites applied any techniques related to sales Promotion as a mere 3.40\% application was observed for this category (see Figure 1). 


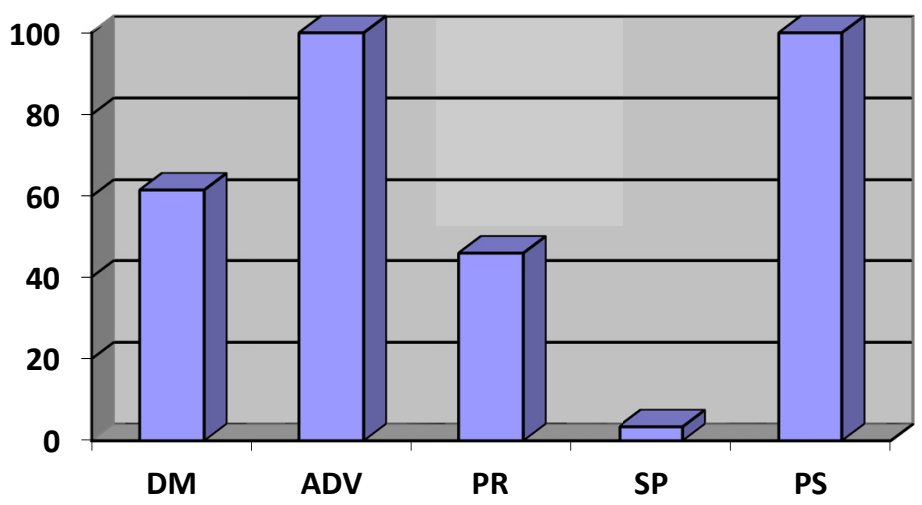

口General Percentage of Marketing Communication Mix techniques Observed

Figure 1. General average percentage of marketing communications mix techniques observed for the sample

This study is not without its limitations. First of all the study was restricted to three, four and five star hotels alone, and to only hotels graded by KITOB the North Cyprus Hoteliers Association. Hence generalizing the findings to all accommodation providers in Northern Cyprus and environs may be problematic. Another limitation of this study is that it only sought to observe the application of the elements of the marketing communications mix and their corresponding techniques, without delving a bit deeper to understand why these elements were present or absent. Also, the conclusions drawn from this study may have assumed that the hoteliers run and maintain their websites themselves. However if that assumption were to be wrong, then the resulting conclusion would be questionable. Thus one key limitation is the assumption that the hoteliers run and manage their websites themselves. One more limitation of this study is the fact that it approached the application of the marketing communications mix from a theoretical perspective, focusing on the ideal, instead of first trying to understand which of the elements of the marketing communications mix or techniques consumers consider to be important or the cultural influences of a particular geographic location such as North Cyprus which may encourage or discourage the application of any element or technique of the marketing mix.

\section{Conclusions}

The need to understand the application of elements of the marketing mix through the website of hoteliers motivated this study. The study began by reviewing previous literature on the existence and application of the elements of the marketing mix and their inherent techniques. 4 elements of the marketing communications mix were identified with constituting techniques summing up to over 30. Since North Cyprus is dependent to a significant degree on tourism, it was expected that local hoteliers will be abreast with the best marketing practices available worldwide. Thus I sought to understand the manner with which they employed the five marketing communications mix Isolated. In order to achieve this, the study observed the website of 33 three, four and five star hotels graded by the North Cyprus Hoteliers Association also called (KITOB). It analyzed the data obtained through qualitatively using the content analysis approach and found that of the five marketing communications mix categories; three were employed entirely along with their constituting techniques while the remaining two were partially applied. These findings contribute to the literature on internet marketing, providing evidence from North Cyprus. While this study did not try to interfere with the research process, which is observatory in nature.

\section{References}

Armstrong, G., \& Kotler, P. (2005). Marketing: an introduction (7th ed.). Upper Saddle River, NewJersey, USA: Pearson/Prentice-Hall.

Belch, G. E., \& Belch, M. A. (2004). Advertising and promotion: an integrated marketingcommunications perspective (6th ed.). New York: McGraw-Hill.

Bennett, A., Jooste, C., \& Strydom, L. (2005). Managing tourism services: A Southern African perspective (3rd ed.). Pretoria, South Africa: Van Schaik.

Cooper, D. R., \& Schindler, P. S. (2003). Business research methods (8th ed.). New York:McGraw-Hill.

Du Plessis, F, Bothma, N., Jordaan, Y., \& van Heerden, N. (2003). Integrated marketing communication. Claremont, South Africa: New Africa Education. 
Duncan, T. (2002). IMC: using advertising and promotion to build brands. USA: McGraw-Hill.

George, R. (2001). Marketing South African tourism and hospitality. Cape Town, South Africa:Oxford University Press.

Lamb, C. W., Hair, J. F., McDaniel, C., Boshoff, C., \& Terblanché, N. S. (2004). Marketing (2nd ed.). Cape Town, South Africa: Oxford University Press.

Lubbe, B. A. (2003). Tourism management in Southern Africa. Cape Town, South Africa:Pearson Education.

Semenik, R. J. (2002). Promotion and integrated marketing communications. Canada: ThomsonLearning.

Shimp, T. A. (2003). Advertising, promotion, \& supplemental aspects of marketing communications (6th ed.). USA: Thomson Learning.

World Travel \& Tourism Council. (2005). South Africa: The 2005 Travel \& Tourism Economic Research report. Retrieved from http://www.wttc.org/2005tsa/pdf/South\%20Africa.pdf

\section{Copyrights}

Copyright for this article is retained by the author(s), with first publication rights granted to the journal.

This is an open-access article distributed under the terms and conditions of the Creative Commons Attribution license (http://creativecommons.org/licenses/by/4.0/). 